\title{
Metabolism and chemical composition of small teleost fishes from tropical inshore waters
}

\author{
Tsutomu Ikeda $^{1,2, *}$, A. David McKinnon ${ }^{1}$, Peter J. Doherty ${ }^{1}$ \\ ${ }^{1}$ Australian Institute of Marine Science, PMB 3 MC, Townsville, Queensland 4810, Australia \\ ${ }^{2}$ Present address: 6-3-1001 Toyokawa-cho, Hakodate 041-8611, Japan
}

\begin{abstract}
Rates of oxygen consumption (R) and ammonia excretion (E) of 29 species of small teleost fishes, which weighed between 1 and $400 \mathrm{mg}$ dry mass (DM), from inshore waters of the Great Barrier Reef were determined at in situ temperatures $\left(25\right.$ to $\left.30^{\circ} \mathrm{C}\right)$. Regression analyses revealed that $\mathrm{R}\left(6.7\right.$ to $1296 \mu \mathrm{O} \mathrm{O}_{2}$ ind. $\left.^{-1} \mathrm{~h}^{-1}\right)$ and $\mathrm{E}\left(0.28\right.$ to $\left.64.2 \mu \mathrm{g} \mathrm{NH} \mathrm{NH}_{4}-\mathrm{N}_{\text {ind }} .^{-1} \mathrm{~h}^{-1}\right)$ were correlated with body mass, but the ratio of $\mathrm{R}$ to $\mathrm{E}$ ( oxygen to nitrogen ratio; 17 to 104 by atoms), was not. Water content of fish bodies ranged from 66.0 to $81.4 \%$ of wet mass (WM), and ash content from 11.9 to $28.6 \%$ of DM. Total carbon $(\mathrm{C})$ and total nitrogen $(\mathrm{N})$ composition varied from 36.2 to $44.4 \%$ and from 8.3 to $12.8 \%$ of DM, respectively, resulting in C:N ratios of 3.1 to 4.7 . Fractions of inorganic $\mathrm{C}$ and $\mathrm{N}$ were small $(0.04$ to $0.33 \%$ and 0.01 to $0.15 \%$ of DM, respectively). Combining $\mathrm{R}$ and $\mathrm{E}$ data with those of body $\mathrm{C}$ and $\mathrm{N}$ composition, daily metabolic losses were estimated to be 4.3 to $18.6 \%$ for body C and 0.8 to $9.1 \%$ for body N. The present R-body mass relationships were compared with the 3 published predictive models for fishes to explore the best fit model. On a body mass basis expressed by N, values for R were consistent with the model for epipelagic zooplankton, but values for E were $30 \%$ lower, suggesting somewhat reduced E relative to R in fishes as compared with zooplankton. Three out of the 29 fishes exhibited markedly high metabolic O:N ratios together with high body C:N ratios, which was interpreted as an adaptation to N-limited detritus nutrition.
\end{abstract}

KEY WORDS: Teleost fish · Oxygen consumption · Ammonia excretion · O:N ratio · Chemical composition $\cdot \mathrm{C}: \mathrm{N}$ ratio $\cdot$ Daily metabolic loss

Resale or republication not permitted without written consent of the publisher

\section{INTRODUCTION}

Fish are regarded as one of the integral components of marine ecosystems, but they are considered to play only a minor role in global biogeochemical cycles because of their smaller biomass and lower specific physiological rates relative to those of bacteria, micro- and mesozooplankton (Conover 1978, del Giorgio \& Duarte 2002). Nevertheless, fish are significant in some regions; e.g., in upwelling systems, anchoveta Engraulis ringens are not only the major consumer of phytoplankton but also a major nutrient regenerator for phytoplankton (Whitledge \& Packard 1971, McCarthy \& Whitledge 1972, Whitledge 1978, 1982). In some reef systems characterized by high productivity but low nutrient concentrations in ambient water, nutrients excreted by resident fish aggregations are quickly utilized by nearby corals or benthic macrophytes (Meyer et al. 1983, Meyer \& Schultz 1985, Bray et al. 1986).
Information about metabolism (oxygen consumption and ammonia excretion rates, $\mathrm{O}: \mathrm{N}$ ratios) and body chemical composition (water content, ash, carbon and nitrogen composition) has proved to be useful in providing a wide perspective for understanding the energy demand, metabolic balance and nutritional condition of marine zooplankton (cf. Ikeda et al. 2000). For fish, oxygen consumption data have been accumulated on diverse species from the world's oceans (Winberg 1956, Post \& Lee 1996, Clarke \& Johnston 1999, Bochdansky \& Leggett 2001 and literature cited therein). While nitrogen metabolism in the early life stages of fish has been studied intensively during the last 2 decades (Wright \& Fyhn 2001, Wood 2001, Finn et al. 2002, Terjesen 2008), nitrogen excretion data are limited (Cockcroft \& Du Preez 1989, Wright \& Fyhn 2001, Wood 2001). The atomic ratio of oxygen consumption rate to ammonia-nitrogen excretion rate (O:N ratio) has been used extensively as an index of 
protein utilization as a metabolic substrate in zooplankton (Mayzaud \& Conover 1988, Ikeda et al. 2000). A similar index, the molar ratio of ammonia excreted to oxygen consumed (ammonia quotient; Kutty 1978) or nitrogen excreted to oxygen consumed (nitrogen quotient; Wright \& Fyhn 2001) has been used as a similar index for fishes, but the available measurements of these indices are largely based on laboratory-raised and maintained fishes. Information about wild fishes is largely limited to the Peruvian anchoveta (Whitledge \& Packard 1971).

Vinogradov (1953) compiled data on the composition of various parts of fishes, including water and ash content and carbon and nitrogen levels. Love (1970) summarized detailed data on water, ash and proximate composition of fishes in relation to their nutritional state. Because of the large body size of fishes in general, carbon and nitrogen composition data on the whole body of fishes are rare and often is limited to the early life stages, such as in grunion Leuresthes tenuis from La Jolla, California (May 1971), sea bream Chrysophrys major from the coasts of Kyushu, southern Japan (Anraku \& Azeta 1973), herring Clupea harengus from the Firth of Clyde (Ehrlich 1974a), plaice Pleuronectes platessa from Scotland (Ehrlich 1974b), and walleye pollock Theragra chalcogramma in the Bering Sea (Harris et al. 1986). The notable exception to this pattern is the availability of such data on all life stages of silvery lightfish Maurolicus muelleri in the Japan Sea (Ikeda 1996). For fishes living in low latitude seas, Beers (1966) analyzed water content and carbohydrate and CNP composition on mixed fish/fish larvae collected with a plankton net off Bermuda. The present study aimed to fill those gaps in knowledge about metabolic and body compositional characteristics of larval and early juvenile teleost fishes in tropical regions. In this study, the term 'larvae' is used broadly; here this term is used not only until the end of the attainment of full external morphological characters, but also until the loss of temporary specializations to pelagic life (cf. Leis and Rennis 1983). The results were compared with those of marine zooplankton and larger fishes to elucidate unique features of tropical fishes, if any exist.

\section{MATERIALS AND METHODS}

Fish sampling. To minimize physical damage of fish specimens, most sampling was done with a light-trap $(37 \times 37 \times 82 \mathrm{~cm})$, deployed along the jetty of the Australian Institute of Marine Science (AIMS) located at Cape Ferguson, North Queensland, during September 2009 and April 2010. For a description of the basic design that includes the advantages of using light-traps for the collection of fishes, see Meekan et al. (2001). The light-trap was submerged just under the surface water in the evening and recovered in the next morning. Fish were sorted, placed into plastic buckets filled with fresh seawater and transported to a constant temperature room. Additional sampling was done on board the RV 'Cape Ferguson' around coastal reefs off Townsville $\left(19^{\circ} \mathrm{S}, 147^{\circ} \mathrm{E}\right)$ and Mackay $\left(20^{\circ} \mathrm{S}, 149^{\circ} \mathrm{E}\right)$ by means of a scoop net when fishes were aggregating under an artificial light at night. Some specimens of each species (1 to 5 ind.) were preserved in $5 \%$ formalin-seawater solution for later identification. Seawater for experiments was collected from the sampling sites of each fish (e.g. near the AIMS jetty for land-based experiments or from $2 \mathrm{~m}$ depth with 101 Niskin bottles for shipboard experiments), filtered through GF/F filters, and aerated to ensure it was well oxygenated prior to use.

Metabolic measurements. Within $2 \mathrm{~h}$ of collection, oxygen consumption and ammonia excretion rates were measured simultaneously with a sealed-chamber method (Ikeda et al. 2000). The fish were rinsed briefly 3 or 4 times with filtered seawater and transferred individually to glass bottles $(100,300,500$ or $1000 \mathrm{ml}$ capacity depending on the size of specimens) filled with filtered seawater. Control bottles without fish were prepared concurrently. In a typical experiment with 6 experimental bottles, 2 control bottles were prepared before the first experimental bottle and 2 after the last experimental bottle. All bottles were incubated for 1 to $5 \mathrm{~h}$ in the dark at near in situ temperatures (25 to $30^{\circ} \mathrm{C}$ ) to obtain significant differences in the concentrations of dissolved oxygen and ammonia between control and experimental bottles. At the end of the incubations, the condition of each fish was checked briefly and duplicate $15 \mathrm{ml}$ (or $70 \mathrm{ml}$ for larger capacity bottles) and $10 \mathrm{ml}$ water samples were siphoned out for the measurements of dissolved oxygen and ammonia, respectively. Fishes with regular operculum movements, whether resting on the bottom of bottles, suspended or gently swimming in the water column, were regarded as 'normal' in this study. Dissolved oxygen and ammonia levels were determined by the Winkler titration method and the phenol-hypochlorite method, respectively (Strickland \& Parsons 1972). Based on replicate measurements on homogenous samples, the precision expressed as coefficient of variation (CV) was $0.2 \%$ for dissolved oxygen determinations and $6 \%$ for ammonia determination in this study. Metabolic rates of fishes thus determined without control of their activities are considered to represent 'routine' metabolism (cf. Fry 1971). Fish left in experimental bottles were rinsed briefly with a small amount of distilled water, blotted on a filter paper to remove water adhering to the body, weighed (wet mass, WM) and frozen for experiments conducted at AIMS. At sea, the speci- 
mens were rinsed briefly with a small amount of distilled water, blotted on the filter paper, stored at $-20^{\circ} \mathrm{C}$, and weighed while frozen (WM) in the laboratory after the cruise.

Chemical composition. In the laboratory, frozen fish were freeze-dried and then oven dried at $60^{\circ} \mathrm{C}$ overnight to remove residual water for the estimation of dry mass (DM) and water content. The dried specimens were pooled by species and then finely ground with a ceramic mortar and pestle. For some species, specimens were separated by size or experimental temperatures (e.g. the same species used in experiments conducted on different dates where in situ temperatures were dissimilar). Powdered samples were used for analysis of total CN composition with an elemental analyzer (TruSpec CN Determinator, LECO) using ethylenediaminetetraacetic acid (EDTA) as a standard. Inorganic C:N composition was analyzed with powdered samples incinerated in a muffle furnace at $450^{\circ} \mathrm{C}$ overnight $(>12 \mathrm{~h})$. For ash determination, weighed fractions of powdered samples were incinerated at $450^{\circ} \mathrm{C}$ overnight and reweighed. All measurements were made in duplicate. From replicate determinations of the same sample, the precision of these analyses (CV) was $3 \%$ for $\mathrm{C}$ and $\mathrm{N}$ and $14 \%$ for ash. Water content was expressed as percent of WM, whereas the contents of ash, carbon and nitrogen were expressed as percent of DM.

Daily metabolic losses in body $\mathbf{C}$ and $\mathbf{N}$. Combining oxygen consumption (R) and ammonia excretion (E) data with body $\mathrm{C}$ and $\mathrm{N}$ compositions, daily metabolic losses in body C (DMC, \% of body C) and N (DMN, $\%$ of body N) can be estimated. R data were converted to $\mathrm{CO}_{2}-\mathrm{C}$ with the following equation, assuming that the dominant metabolic substrate of fishes in feeding is protein (cf. Wood 2001, Finn et al. 2002) and ammonia is the only end product of protein: $\mathrm{DMC}=\mathrm{R} \times 0.97 \times$ $24 \times(12 / 22.4) \times 10^{-3} \times 100(\mathrm{mg} \text { body } \mathrm{C})^{-1}$, where 0.97 is the respiratory quotient $(\mathrm{RQ})$ for protein metabolism characterized by ammonia as the sole end product (Gnaiger 1983), 24 is the number of $\mathrm{h} \mathrm{d}^{-1}, 12 / 22.4$ is the $\mathrm{C}$ mass in $1 \mathrm{~mol}$ of $\mathrm{CO}_{2}(22.4 \mathrm{l})$ and $10^{-3}$ is to convert $\mu \mathrm{g}$ to mg. Similarly: $\mathrm{DMN}=\mathrm{E} \times 24 \times 10^{-3} \times 100(\mathrm{mg}$ body $N)^{-1}$, where 24 and $10^{-3}$ are the same as defined for DMC.

Statistical treatment of the data. Means $( \pm 1 \mathrm{SD})$ are given throughout the text and tables. For analyzing the effects of body mass $\left(X_{1}\right)$ and temperature $\left(X_{2}\right)$ on metabolic rate $(Y)$, the regression model used for marine epipelagic zooplankton (Ikeda 1985) was adopted: $\ln Y=a_{0}+a_{1} \ln X_{1}+a_{2} X_{2}$, where $a_{0}$ (intercept), $\mathrm{a}_{1}$ and $\mathrm{a}_{2}$ are coefficients. Student's $t$-tests were used to judge significance of the coefficient at $p=0.05$ unless otherwise noted. For the comparison of R or E of fishes observed with those predicted from the models of pre- vious research (Winberg 1956, Clarke \& Johnston 1999, Bochdansky \& Leggett 2001, Ikeda 1985), Wilcoxon signed-rank tests were used. All these calculations were conducted using SYSTAT version 10.2.

\section{RESULTS}

\section{Oxygen consumption and ammonia excretion}

Of 29 fish species belonging to 22 families studied, 18 species were common coral reef fishes of the Great Barrier Reef province (Table 1). The results of Caracanthus sp. and Neomyxus sp. were separated into 2 size groups, and those of Ambassis sp., Hypoatherina sp., Lethrinus sp. and Monocanthus sp. were divided into 2 temperature groups, yielding a total of 35 data sets. The ranges of fish body masses were 6.3 to $1786 \mathrm{mg}$ for WM and 1.24 to $395 \mathrm{mg}$ for DM. Experimental temperatures were adjusted to the range of temperatures observed in the field $\left(25\right.$ to $\left.30^{\circ} \mathrm{C}\right)$. Oxygen saturation of experimental bottles at the end of experiments varied considerably (49 to $97 \%$, mean $=80 \%$ ) but was well above the 15 to $33 \%$ level that is critical for coral reef fishes (Nilsson \& Östlund-Nilsson 2006). R and $\mathrm{E}$ varied from 6.73 to $1296 \mu \mathrm{O} \mathrm{O}_{2}$ ind. $^{-1} \mathrm{~h}^{-1}$ and from 0.28 to $64.2 \mu \mathrm{g} \mathrm{NH} \mathrm{NH}_{4} \mathrm{~N}$ ind. ${ }^{-1} \mathrm{~h}^{-1}$, respectively (Table 2 ). Preliminary analysis using the multiple regression model see 'Statistical treatment of the data' section) assigning $X_{1}$ and $X_{2}$ to be DM and temperature, respectively, showed that the coefficient $\mathrm{a}_{1}$ was highly significant ( $t$-test, df $=32, \mathrm{p}<0.01$ ) for both $\mathrm{R}$ and $\mathrm{E}$, but $\mathrm{a}_{2}$ was not significant ( $t$-test, $\mathrm{df}=32, \mathrm{p}>0.60$ for $\mathrm{R}$, and $\mathrm{p}>0.90$ for E). From these results, $X_{2}$ was ignored, and $\mathrm{R}$ and $\mathrm{E}$ of the fishes were expressed as a function of $X_{1}$ $\left(\mathrm{R}^{2}=0.9270, \mathrm{df}=33, \mathrm{p}<0.01\right.$ and $\mathrm{R}^{2}=0.8156, \mathrm{df}=33$, $\mathrm{p}<0.01$, respectively, Fig. 1).

\section{$\mathrm{O}: \mathrm{N}$ ratio}

Based on apparent nitrogen quotients (NQ) in which nitrogen is represented by ammonia only, Finn \& Rønnestad (2003) proposed a set of equations to calculate the mass fraction of protein catabolized simultaneously with carbohydrate: $\mathrm{K}_{\mathrm{p}}=3.221(\mathrm{NQ})+2.571(\mathrm{NQ})^{2}$ $+4.064(\mathrm{NQ})^{3}$, or lipid: $\mathrm{K}_{\mathrm{p}}=8.069(\mathrm{NQ})-25.267(\mathrm{NQ})^{2}+$ $36.732(\mathrm{NQ})^{3}$, in fish. When only protein is metabolized in fish, $\mathrm{NQ}=0.24$, which is equivalent to $\mathrm{O}: \mathrm{N}=8.2$ because $N Q=2$ / O:N. In this way, O:N ratios for a fish catabolizing protein and carbohydrate or lipid of equal amounts at the same time are calculated as 14.6 or 25.0 (mid-point: 20). Then, O:N ratios of 8 to 20 may be used as an index of protein-oriented metabolism, and ratios of $>20$ as lipid/carbohydrate oriented metabolism. 
Table 1. Species of juvenile and early juvenile fishes collected in the Great Barrier Reef, Australia, and sampling methods used

\begin{tabular}{|c|c|c|c|c|c|}
\hline $\begin{array}{l}\text { Species } \\
\text { code }\end{array}$ & Scientific name & Common name & Family & Sampling site & $\begin{array}{l}\text { Sampling } \\
\text { method }\end{array}$ \\
\hline $\mathrm{AB}$ & Abudefduf vagiensis ${ }^{\mathrm{a}}$ & Seargeant-major & Pomacentridae & Cape Ferguson coast & Light-trap \\
\hline AM1, AM2 & Ambassis sp. . $^{\text {a }}$ & Glassy & Ambassidae & Cape Ferguson coast & Light-trap \\
\hline $\mathrm{AE}$ & Amblyeleotris sp. ${ }^{\mathrm{a}}$ & Goby & Gobiidae & Cape Ferguson coast & Light-trap \\
\hline AG & Amblygobius sp. ${ }^{\text {a }}$ & Goby & Gobiidae & Cape Ferguson coast & Light-trap \\
\hline $\mathrm{AP}$ & Apogon sp. ${ }^{\mathrm{a}}$ & Soldierfish/Cardinalfish & Apogonidae & Cape Ferguson coast & Light-trap \\
\hline CA1, CA2 & Caracanthus sp. ${ }^{\mathrm{a}, \mathrm{c}}$ & Croucher & Caracanthidae & Cape Ferguson coast & Scoop net \\
\hline $\mathrm{CHA}$ & Chaetodon rainfordi ${ }^{\mathrm{a}}$ & Northern butterflyfish & Chaetodontidae & Cape Ferguson coast & Light-trap \\
\hline $\mathrm{CHR}$ & Chromis viridis ${ }^{\mathrm{a}}$ & Blue puller & Pomacentridae & Off Townsville & Light-trap \\
\hline $\mathrm{G}$ & Gerres sp. ${ }^{\mathrm{a}}$ & Silverbelly & Gerreidae & Cape Ferguson coast & Light-trap \\
\hline $\mathrm{HE}$ & Herklotsichthys sp. & Tropical herring & Clupeidae & Off Mackay & Scoop net \\
\hline HY1, HY2 & Hypoatherina sp. ${ }^{\mathrm{a}, \mathrm{b}}$ & Silverside/Whitebait & Athernidae & Off Mackay & Scoop net \\
\hline LEI & Leiognathus sp. & Ponyfish & Leiognathidae & Cape Ferguson coast & Light-trap \\
\hline LET1, LET2 & Lethrinus sp. ${ }^{\mathrm{a}, \mathrm{b}}$ & Sweetlip & Lethrinidae & Cape Ferguson coast & Light-trap \\
\hline LU & Lutjanus carponotatus $^{\mathrm{a}}$ & Stripey & Lutjanidae & Cape Ferguson coast & Light-trap \\
\hline MO1, MO2 & Monacanthidae sp. ${ }^{\mathrm{a}, \mathrm{b}}$ & Leatherjacket & Monananthidae & Cape Ferguson coast & Light-trap \\
\hline MU & Mullidae sp. ${ }^{\text {a }}$ & Goatfish & Mullidae & Cape Ferguson coast & Light-trap \\
\hline NM1, NM2 & Neomyxus sp. ${ }^{\mathrm{c}}$ & Mullet & Mugilidae & Cape Ferguson coast & Scoop net \\
\hline NP & Neopomacentrus bankieri ${ }^{\mathrm{a}}$ & Damselfish & Pomacentridae & Cape Ferguson coast & Light-trap \\
\hline $\mathrm{O}$ & Omobranchus sp. ${ }^{\mathrm{a}}$ & Blenny & Blenniidae & Cape Ferguson coast & Light-trap \\
\hline $\mathrm{PE}$ & Pelates quadrilineatus & Trumpeter & Terapontidae & Cape Ferguson coast & Scoop net \\
\hline $\mathrm{PO}$ & Pomacentrus sp. ${ }^{\mathrm{a}}$ & Damselfish & Pomacentridae & Off Mackay & Scoop net \\
\hline SCA & Scatophagus sp. & Butterfish & Scatophagidae & Cape Ferguson coast & Light-trap \\
\hline SL & Scomberoides lysan & Queenfish & Scombridae & Cape Ferguson coast & Light-trap \\
\hline SQ & $\begin{array}{l}\text { Scomberomorus } \\
\text { queenslandicus }\end{array}$ & School mackerel & Scombridae & Cape Ferguson coast & Light-trap \\
\hline $\mathrm{SE}$ & Selaroides leptolepis & Smooth-tailed travally & Carangidae & Cape Ferguson coast & Light-trap \\
\hline SI & Siganus sp. ${ }^{\mathrm{a}}$ & Spinefoot & Siganidae & Cape Ferguson coast & Light-trap \\
\hline SP & Sphyraena sp. ${ }^{\mathrm{a}}$ & Sea-pike & Sphyraenidae & Cape Ferguson coast & Light-trap \\
\hline $\mathrm{T}$ & Terapon sp. & Trumpeter & Teraponidae & Cape Ferquson coast & Scoop net \\
\hline $\mathrm{U}$ & Upeneus tragula ${ }^{a}$ & Blackstriped goatfish & Mullidae & Cape Ferguson coast & Light-trap \\
\hline
\end{tabular}

$\mathrm{O}: \mathrm{N}$ ratios of the fishes in this study ranged from 17.3 to 104 with a mean \pm 1 SD of $38.3 \pm 22.0$ (Table 2 ), suggesting lipid/carbohydrate oriented metabolism. O:N ratios were found to be independent of body mass $\left(\mathrm{R}^{2}=\right.$ 0.0124, df = 33, p > 0.05, Fig. 1).

\section{Water, ash and elemental composition}

Across the 35 data sets, water content varied from 66.0 to $81.4 \% \mathrm{WM}$ with a mean of $76.5 \%( \pm 3.6)$, and ash content from 11.9 to $28.6 \%$ DM with a mean of $17.8 \%( \pm 3.3)$ (Table 3$)$. The ranges of total $\mathrm{C}$ and $\mathrm{N}$ composition were 36.2 to $44.4 \%$ DM with a mean of $41.2 \%( \pm 1.8)$ and 8.3 to $12.8 \%$ DM with a mean of $11.4 \%( \pm 1.0)$, respectively, yielding $\mathrm{C}: \mathrm{N}$ ratios of 3.1 to 4.7 with a mean of $3.6( \pm 0.4)$ by mass. Fractions of inorganic $\mathrm{C}$ and $\mathrm{N}$ in the total were small, ranging from 0.04 to $0.33 \% \mathrm{DM}$ with a mean of $0.14 \%( \pm 0.07)$ and from 0.01 to $0.15 \%$ DM with a mean of $0.05 \%( \pm 0.03)$, respectively (Table 3 ).
From the information about elemental CN composition of typical protein $(\mathrm{C}, 52.9 \%$; N $17.3 \%)$, carbohydrate $(\mathrm{C}$, $44.4 \% ; \mathrm{N}, 0 \%)$ and lipid $(\mathrm{C}, 77.6 \% ; \mathrm{N}, 0 \%)$ in Gnaiger \& Bitterlich (1984), the proportion of protein in organic matter (which is equal to ash-free DM) can be estimated. For organic matter composed of protein alone a $\mathrm{C}: \mathrm{N}$ ratio $=$ 3.1 is computed, and for organic matter of which one half is composed by protein and the other half by lipid, a C:N ratio $=7.5$ can be used. Carbohydrate in fishes has been reported as $<1 \%$ of DM (Beers 1966) or $<2 \%$ of ash-free DM (Childress \& Nygaard 1973) and is therefore omitted in further calculations.

\section{Daily metabolic losses in body $\mathbf{C}$ and $\mathbf{N}$}

Body $\mathrm{C}$ and $\mathrm{N}$ were represented by total $\mathrm{C}$ and $\mathrm{N}$, since the fractions of inorganic $\mathrm{C}$ and $\mathrm{N}$ in the total were very small (Table 3). Resultant DMC and DMN values were 4.3 to $18.6 \%$ with a mean of $10.0 \%( \pm 3.3)$ and 0.8 to $9.1 \%$ with a mean of $3.3 \%( \pm 1.9)$, respectively (Table 2$)$. 
Table 2. Mean \pm SD oxygen consumption $(\mathrm{R})$ and ammonia excretion $(\mathrm{E})$, calculated metabolic oxygen to nitrogen (O:N) ratios and daily metabolic losses in body carbon $(\mathrm{C})$ and body nitrogen $(\mathrm{N})$ of 29 larval and early juvenile fish species. For species codes, see

Table 1. WM: wet mass; DM: dry mass; nd: no data

\begin{tabular}{|c|c|c|c|c|c|c|c|c|c|}
\hline \multirow{2}{*}{$\begin{array}{l}\text { Species } \\
\text { code }\end{array}$} & \multirow{2}{*}{$\begin{array}{c}\begin{array}{c}\text { Temperature } \\
\left({ }^{\circ} \mathrm{C}\right)\end{array} \\
29\end{array}$} & \multirow{2}{*}{$\begin{array}{l}\mathrm{N} \\
3\end{array}$} & \multicolumn{2}{|c|}{ 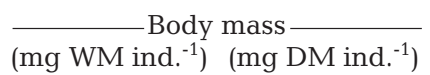 } & \multirow{2}{*}{$\begin{array}{c}\begin{array}{c}\mathrm{R}\left(\mu \mathrm{l} \mathrm{O} \mathrm{O}_{2}\right. \\
\left.\text { ind. }^{-1} \mathrm{~h}^{-1}\right)\end{array} \\
395.7 \pm 163.3\end{array}$} & \multirow{2}{*}{$\begin{array}{c}\begin{array}{c}\mathrm{E}\left(\mu \mathrm{g} \mathrm{NH} \mathrm{NH}_{4}-\mathrm{N}\right. \\
\left.\text { ind. }^{-1} \mathrm{~h}^{-1}\right)\end{array} \\
55.85 \pm 42.30\end{array}$} & \multirow{2}{*}{$\begin{array}{c}\begin{array}{c}\text { O:N ratio } \\
\text { (by atoms) }\end{array} \\
17.5 \pm 17.1\end{array}$} & \multicolumn{2}{|c|}{$\begin{array}{c}\text { Daily metabolic loss } \\
\text { (\% body } \mathrm{C})(\% \text { body } \mathrm{N})\end{array}$} \\
\hline & & & $477.7 \pm 208.8$ & $114.64 \pm 53.35$ & & & & $10.6 \pm 1.3$ & $9.13 \pm 6.05$ \\
\hline $\mathrm{AM} 2^{\mathrm{a}}$ & 29 & 5 & $355.3 \pm 101.4$ & $87.68 \pm 25.69$ & $121.2 \pm 31.2$ & $3.52 \pm 1.23$ & $44.5 \pm 6.4$ & $4.4 \pm 0.3$ & $0.82 \pm 0.10$ \\
\hline $\mathrm{AE}$ & 29 & 2 & $58.3 \pm 2.3$ & $10.87 \pm 0.91$ & $32.0 \pm 3.4$ & $1.05 \pm 0.19$ & $38.5 \pm 2.8$ & $8.9 \pm 0.2$ & $1.87 \pm 0.18$ \\
\hline AG & 30 & 6 & $47.6 \pm 20.5$ & $9.96 \pm 4.49$ & $14.4 \pm 5.9$ & $0.94 \pm 0.65$ & $22.2 \pm 5.5$ & $4.6 \pm 0.8$ & $1.83 \pm 0.49$ \\
\hline $\mathrm{CA} 2^{\mathrm{b}}$ & 28 & 3 & $28.4 \pm 9.7$ & $5.67 \pm 2.15$ & $22.9 \pm 7.4$ & $0.66 \pm 0.23$ & $43.9 \pm 9.6$ & $12.0 \pm 1.3$ & $2.66 \pm 0.35$ \\
\hline CHA & 29 & 5 & $169.9 \pm 59.1$ & $52.56 \pm 17.06$ & $113.1 \pm 25.9$ & $2.08 \pm 0.64$ & $74.0 \pm 32.1$ & $7.2 \pm 1.0$ & $1.25 \pm 0.51$ \\
\hline $\mathrm{CHR}$ & 29 & 6 & $31.9 \pm 2.3$ & $9.17 \pm 0.68$ & $36.2 \pm 1.9$ & $0.45 \pm 0.10$ & $104.4 \pm 20.1$ & $11.2 \pm 0.7$ & $1.25 \pm 0.26$ \\
\hline G & 29 & 2 & $74.7 \pm 19.7$ & $15.39 \pm 4.06$ & $53.5 \pm 22.3$ & $1.56 \pm 0.13$ & $43.6 \pm 21.3$ & $11.1 \pm 1.8$ & $2.09 \pm 0.71$ \\
\hline $\mathrm{HE}$ & 27 & 4 & $129.6 \pm 68.6$ & $41.22 \pm 18.77$ & $179.1 \pm 90.0$ & $8.33 \pm 2.36$ & $27.0 \pm 10.3$ & $12.2 \pm 2.2$ & $4.39 \pm 2.25$ \\
\hline$H Y 1^{a}$ & 26 & 6 & $182.3 \pm 70.8$ & $55.57 \pm 21.44$ & $199.5 \pm 50.8$ & $5.00 \pm 3.36$ & $66.0 \pm 34.4$ & $10.6 \pm 1.8$ & $2.05 \pm 1.58$ \\
\hline $\mathrm{HY} 2^{\mathrm{a}}$ & 29 & 3 & $225.3 \pm 49.7$ & $60.79 \pm 11.96$ & $251.6 \pm 47.0$ & $6.10 \pm 2.54$ & $57.9 \pm 25.3$ & $11.8 \pm 1.3$ & $2.09 \pm 0.91$ \\
\hline $\mathrm{MO}^{\mathrm{a}}$ & 29 & 3 & $217.9 \pm 31.3$ & $45.92 \pm 5.49$ & $139.7 \pm 15.4$ & $4.83 \pm 2.87$ & $46.5 \pm 26.8$ & $8.9 \pm 0.2$ & $2.17 \pm 1.19$ \\
\hline $\mathrm{MO}^{\mathrm{a}}$ & 30 & 10 & $285.7 \pm 76.9$ & $59.26 \pm 17.33$ & $182.8 \pm 52.6$ & $11.01 \pm 8.31$ & $30.9 \pm 17.7$ & $9.4 \pm 2.0$ & $4.05 \pm 3.18$ \\
\hline MU & 29 & 3 & $80.4 \pm 26.9$ & $18.38 \pm 6.29$ & $80.8 \pm 16.9$ & $5.13 \pm 1.91$ & $20.8 \pm 4.6$ & $14.0 \pm 2.4$ & $5.23 \pm 0.67$ \\
\hline $\mathrm{NM}^{\mathrm{b}}$ & 28 & 16 & $27.6 \pm 4.0$ & $6.10 \pm 0.85$ & $26.4 \pm 5.6$ & $2.14 \pm 1.88$ & $21.7 \pm 10.2$ & $12.7 \pm 1.8$ & $7.10 \pm 5.34$ \\
\hline $\mathrm{NM} 2^{\mathrm{b}}$ & 28 & 4 & $45.7 \pm 9.1$ & $14.97 \pm 4.35$ & $39.9 \pm 13.2$ & $2.84 \pm 0.80$ & $17.7 \pm 4.8$ & $8.7 \pm 3.9$ & $4.76 \pm 2.31$ \\
\hline NP & 28 & 6 & $347.8 \pm 58.7$ & $87.50 \pm 14.46$ & $153.7 \pm 26.8$ & $9.74 \pm 3.16$ & $20.6 \pm 3.5$ & $5.6 \pm 0.5$ & $2.33 \pm 0.46$ \\
\hline $\mathrm{O}$ & 30 & 6 & $24.2 \pm 6.9$ & $5.90 \pm 1.74$ & $17.7 \pm 2.5$ & $0.38 \pm 0.06$ & $60.0 \pm 12.9$ & $9.4 \pm 1.3$ & $1.43 \pm 0.43$ \\
\hline $\mathrm{PE}$ & 28 & 6 & $19.2 \pm 1.8$ & $3.94 \pm 0.42$ & $9.4 \pm 0.6$ & $0.49 \pm 0.11$ & $24.9 \pm 4.9$ & $7.0 \pm 0.4$ & $2.56 \pm 0.41$ \\
\hline $\mathrm{PO}$ & 25 & 3 & nd & $15.27 \pm 0.69$ & $54.1 \pm 16.1$ & $2.14 \pm 0.92$ & $34.1 \pm 12.8$ & $10.7 \pm 3.4$ & $2.98 \pm 1.32$ \\
\hline $\mathrm{SCA}$ & 29 & 4 & $90.4 \pm 7.5$ & $24.30 \pm 2.69$ & $71.6 \pm 25.5$ & $0.97 \pm 0.31$ & $93.3 \pm 20.4$ & $9.0 \pm 2.7$ & $1.03 \pm 0.39$ \\
\hline SL & 30 & 2 & $565.1 \pm 352.8$ & $132.5 \pm 85.8$ & $410.9 \pm 432.2$ & $29.52 \pm 34.62$ & $21.3 \pm 6.7$ & $8.0 \pm 4.9$ & $3.33 \pm 2.82$ \\
\hline $\mathrm{SQ}$ & 29 & 3 & $733.7 \pm 68.3$ & $142.1 \pm 16.1$ & $880.8 \pm 164.4$ & $18.20 \pm 8.20$ & $66.4 \pm 20.5$ & $18.2 \pm 1.4$ & $2.38 \pm 0.83$ \\
\hline $\mathrm{SE}$ & 29 & 4 & $1786 \pm 278$ & $394.8 \pm 64.1$ & $1296 \pm 206.5$ & $64.23 \pm 9.99$ & $26.2 \pm 8.2$ & $10.5 \pm 2.9$ & $3.16 \pm 0.53$ \\
\hline SI & 29 & 6 & $352.1 \pm 51.5$ & $77.83 \pm 16.28$ & $203.0 \pm 31.4$ & $13.95 \pm 3.44$ & $19.4 \pm 6.1$ & $8.2 \pm 1.2$ & $3.96 \pm 1.35$ \\
\hline
\end{tabular}

\section{DISCUSSION}

\section{Metabolic comparison}

While fishes show considerable variation in systematics, morphology, ecology and body size, their oxygen consumption rates are known to be governed ultimately by body mass, and metabolic models are based on various concepts, assumptions and data sources. Among many models published (Post \& Lee 1996, Bochdansky \& Leggett 2001), those of Winberg (1956), Clarke \& Johnston (1999), and Bochdansky \& Leggett (2001) were selected to compare with the present results because these references contain comprehensive data sets of diverse fishes. The models of Winberg (1956) and Clarke \& Johnston (1999) are characterized by body mass (WM, mg) and temperature $\left(t,{ }^{\circ} \mathrm{C}\right)$ as independent variables, and that of Bochdansky \& Leggett (2001) by body mass only.

The Winberg (1956) model predicts 'routine metabolism' (normal activity) from the formula: $\mathrm{R}=\mathrm{R}_{20} \mathrm{q}^{-1}=(1.37$ $\left.\times \mathrm{WM}^{0.79}\right) \mathrm{q}^{-1}$, where $\mathrm{R}_{20}$ is $\mathrm{R}$ at $20^{\circ} \mathrm{C}$ and $\mathrm{q}$ is $\mathrm{Q}_{10}$ to convert $\mathrm{R}_{20}$ to $\mathrm{R}$ at $t^{\circ} \mathrm{C}$ or vice versa (Table 1 in Winberg 1956). The Clarke \& Johnston (1999) model predicts 'standard' or 'resting' metabolism (no activity) from the formula: $\ln R=0.8 \times \ln (\mathrm{WM} / 1000)+(15.7-5.0 \times$ $1000 /(273.2+t))-0.8 \times \ln (50)$, where $\mathrm{R}$ is mmol $\mathrm{O}_{2}$ ind. $^{-1}$ $\mathrm{h}^{-1} . \mathrm{R}$ is doubled ('routine' metabolism = 'standard' metabolism $\times 2$, cf. Bochdansky \& Leggett 2001) and finally converted to $\mathrm{R}\left(\mu \mathrm{l} \mathrm{O}_{2}\right.$ ind $\left.^{-1} \mathrm{~h}^{-1}\right): \mathrm{R}=(\operatorname{expR}) \times 2 \times$ $22.4 \times 1000$. While Winberg's (1956) and Clarke \& Johnston's (1999) analyses used juvenile and adult fishes, 

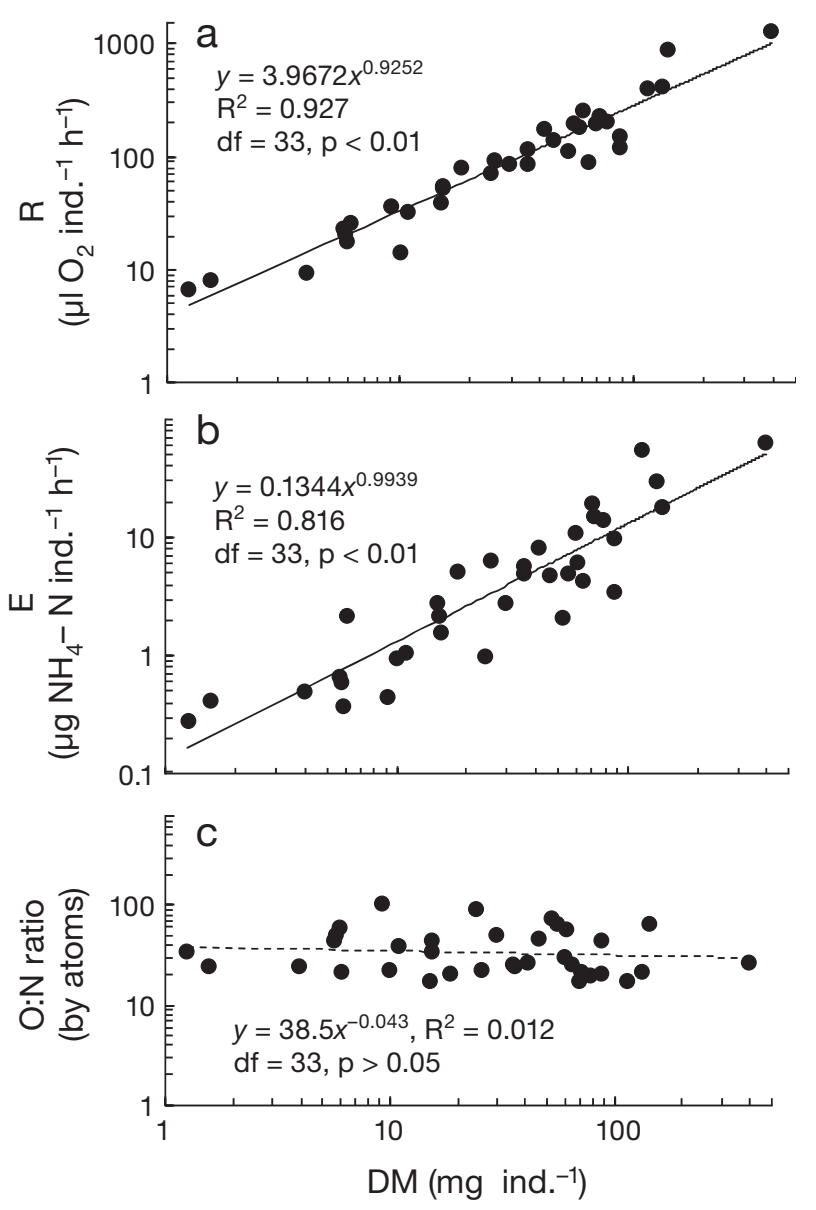

Fig. 1. Relationships between dry mass (DM) and (a) oxygen consumption rates (R), (b) ammonia excretion rates (E) and (c) oxygen consumption rate to ammonia excretion rate ratios (O:N). Data points are means of 35 data sets on 29 fish species listed in Table 2. Solid regression lines show significant relationships, while those with dashed lines were not

Bochdansky \& Leggett's (2001) analysis included larval fishes in addition to juvenile and adult fishes. In contrast to the 2 models mentioned above, Bochdansky \& Leggett's model has only one variable (body mass) because temperature was shown to be not important relative to body dry mass (DM, mg). Their model is written as: $\log _{10} \mathrm{R}=(1000 / 24) \times \log _{10}(1 /(\mathrm{A}+\mathrm{B}))$, where $\mathrm{A}=$ $1 / 10^{\left(-3.71+\log _{10} \mathrm{DM}\right)}$ and $\mathrm{B}=1 / 10^{\left(-2.40+0.67 \times \log _{10} \mathrm{DM}\right)}$. Predicted Rs from these 3 models are plotted against observed Rs (Fig. 2) and the differences between the 2 were tested by the Wilcoxon signed-rank test (null hypothesis: Rs predicted match those observed). The null hypothesis was rejected for Rs predicted by the Clarke \& Johnston model $(\mathrm{p}<0.001)$, and the Winberg model $(\mathrm{p}<$ 0.05); the former yielded Rs 1.8 times and the latter 1.6 times greater than those observed. On the other hand, the null hypothesis was accepted for Rs predicted by the Bochdansky \& Leggett model ( $p>0.95)$. This result may

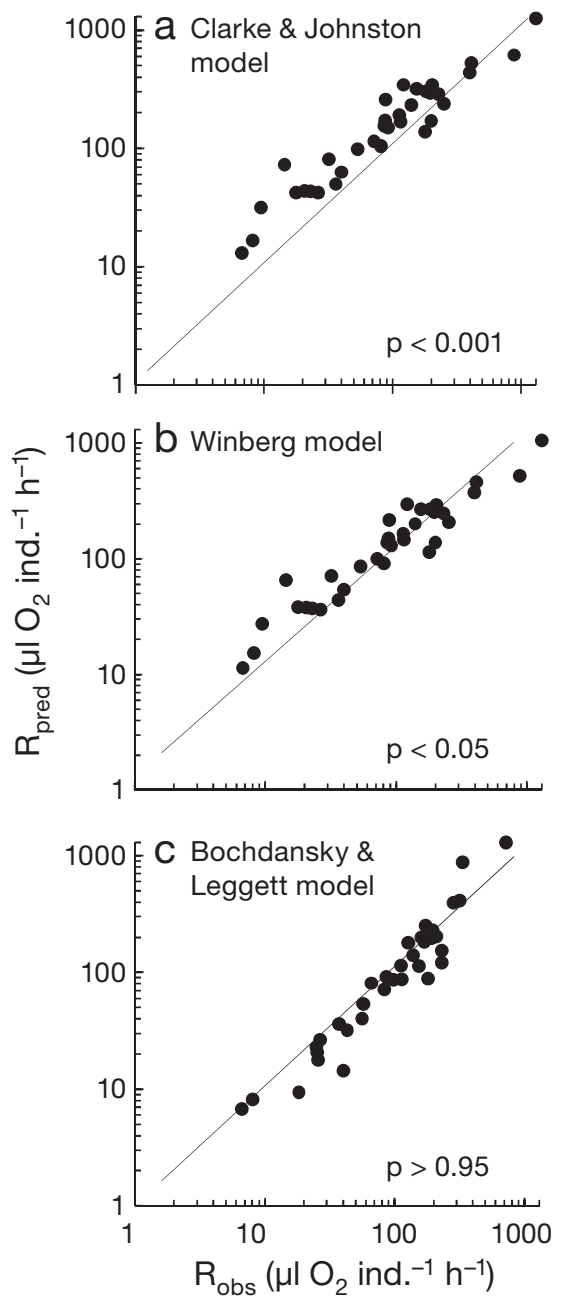

Fig. 2. Comparison of oxygen consumption rates observed $\left(\mathrm{R}_{\text {obs }}\right)$ with those predicted $\left(\mathrm{R}_{\text {pred }}\right)$ from fish metabolism models of (a) Clarke \& Johnston (1999), (b) Winberg (1956) and (c) Bochdansky \& Leggett (2001). Models were based on fish body mass and temperature data for a and b, and body mass only for c. Data points are means of 35 data sets on 29 fish species listed in Table 2. To facilitate comparison, a 1:1 relationship was superimposed

be due to the fact that the body mass of fishes of this study (6.3 to $1786 \mathrm{mg}$ WM or 1.24 to $395 \mathrm{mg}$ DM, Table 2) only partially overlap those (87 to $870000 \mathrm{mg}$ WM) of Winberg (1956) and those (400 to $3000000 \mathrm{mg}$ WM) of Clarke \& Johnston (1999), but fall well within those (0.001 to $100000 \mathrm{mg}$ DM) of Bochdansky \& Leggett (2001). In addition, metabolic rate-body mass relationships of larval fishes, which may be disproportionally lower than those of juvenile/adult fishes (Post \& Lee 1996), are taken into account in the Bochdansky \& Leggett (2001) model but not in the Winberg (1956) or Clarke \& Johnston (1999) models.

All the fishes used in the present study were small pelagic species (or pelagic stages of benthic species) as 
Table 3. Mean \pm SD water and mean ash content, total $C$ and $N$ composition, C:N ratio and inorganic $\mathrm{C}$ and $\mathrm{N}$ composition of 29 larval and early juvenile fishes. For species codes, see Table 1, and for the number of replicates of each species see Table 2. WM: wet mass; DM: dry mass; nd: no data

\begin{tabular}{|c|c|c|c|c|c|c|c|}
\hline $\begin{array}{l}\text { Species } \\
\text { code }\end{array}$ & $\begin{array}{c}\text { Water } \\
(\% \text { of WM) }\end{array}$ & Ash & $\begin{array}{c}\text { Total C } \\
\text { \% of DM }\end{array}$ & Total N & $\begin{array}{c}\mathrm{C}: \mathrm{N} \\
\text { by mass) }\end{array}$ & $\begin{array}{r}\text { Inorg C } \\
(\% \text { o }\end{array}$ & $\begin{array}{l}\text { Inorg } N \\
\text { DM) }\end{array}$ \\
\hline$A B$ & $76.2 \pm 0.8$ & 17.8 & 41.4 & 11.2 & 3.7 & 0.13 & 0.06 \\
\hline $\mathrm{AM}^{\mathrm{a}}$ & $75.9 \pm 1.1$ & 20.6 & 40.6 & 11.7 & 3.5 & 0.13 & 0.01 \\
\hline $\mathrm{AM} 2^{\mathrm{a}}$ & $75.4 \pm 0.4$ & 20.5 & 39.8 & 11.6 & 3.4 & 0.17 & 0.03 \\
\hline $\mathrm{AE}$ & $81.4 \pm 0.8$ & 17.6 & 41.0 & 12.3 & 3.3 & nd & nd \\
\hline AG & $79.2 \pm 0.7$ & 20.5 & 40.6 & 11.6 & 3.5 & 0.33 & 0.15 \\
\hline $\mathrm{AP}$ & $79.6 \pm 0.3$ & 14.9 & 36.2 & 11.3 & 3.2 & nd & nd \\
\hline $\mathrm{CA} 1^{\mathrm{b}}$ & $80.4 \pm 0.4$ & nd & 42.6 & 10.7 & 4.0 & nd & nd \\
\hline $\mathrm{CA} 2^{\mathrm{b}}$ & $80.2 \pm 0.9$ & 16.7 & 42.1 & 11.2 & 3.8 & nd & nd \\
\hline CHA & $68.8 \pm 1.0$ & 28.6 & 38.8 & 8.3 & 4.7 & 0.09 & 0.03 \\
\hline CHR & $71.2 \pm 0.6$ & 17.9 & 44.1 & 9.4 & 4.7 & 0.16 & 0.06 \\
\hline $\mathrm{G}$ & $79.4 \pm 0.0$ & 18.4 & 40.1 & 12.6 & 3.2 & 0.07 & 0.04 \\
\hline $\mathrm{HE}$ & $66 \pm 9.6$ & 14.5 & 44.5 & 12.5 & 3.5 & 0.10 & 0.04 \\
\hline $\mathrm{HY}^{\mathrm{a}}{ }^{\mathrm{a}}$ & $69.1 \pm 4.2$ & 16.2 & 44.4 & 12.2 & 3.6 & 0.12 & 0.03 \\
\hline $\mathrm{HY}^{\mathrm{a}}$ & $72.9 \pm 1.1$ & 15.7 & 43.9 & 11.8 & 3.7 & 0.13 & 0.03 \\
\hline LEI & $75.7 \pm 0.4$ & 16.4 & 40.1 & 12.8 & 3.1 & 0.10 & 0.03 \\
\hline LET1 $^{\mathrm{a}}$ & $76.3 \pm 0.6$ & 19.0 & 40.9 & 10.9 & 3.8 & 0.13 & 0.04 \\
\hline LET2 $^{\text {a }}$ & $76 \pm 0.8$ & 20.3 & 42.5 & 11.0 & 3.9 & 0.13 & 0.04 \\
\hline LU & $76.3 \pm 1.0$ & 18.7 & 41.5 & 11.1 & 3.8 & 0.12 & 0.04 \\
\hline $\mathrm{MO}^{\mathrm{a}}$ & $78.9 \pm 0.6$ & 16.2 & 42.8 & 11.3 & 3.8 & 0.06 & 0.07 \\
\hline $\mathrm{MO}^{\mathrm{a}}$ & $79.4 \pm 0.8$ & 17.1 & 41.8 & 11.5 & 3.7 & 0.06 & 0.04 \\
\hline MU & $77.2 \pm 0.2$ & 15.6 & 40.6 & 12.7 & 3.2 & nd & nd \\
\hline NM1 ${ }^{b}$ & $77.8 \pm 0.7$ & 15.3 & 43.2 & 11.9 & 3.6 & 0.23 & 0.11 \\
\hline$N M 2^{b}$ & $77.1 \pm 1.0$ & 16.2 & 39.7 & 10.3 & 3.9 & 0.22 & 0.06 \\
\hline NP & $74.8 \pm 0.4$ & 24.1 & 39.4 & 11.3 & 3.5 & 0.12 & 0.04 \\
\hline $\mathrm{O}$ & $75.6 \pm 0.4$ & 17.6 & 41.1 & 11.4 & 3.6 & nd & nd \\
\hline PE & $79.5 \pm 0.5$ & 11.9 & 42.6 & 11.6 & 3.7 & 0.31 & 0.10 \\
\hline $\mathrm{PO}$ & nd & 13.8 & 41.8 & 11.3 & 3.7 & nd & nd \\
\hline SCA & $73.2 \pm 0.8$ & 22.1 & 40.7 & 9.5 & 4.3 & 0.13 & 0.12 \\
\hline SL & $76.8 \pm 0.7$ & 16.6 & 38.1 & 12.2 & 3.1 & nd & nd \\
\hline $\mathrm{SQ}$ & $80.7 \pm 0.4$ & 14.0 & 42.3 & 12.6 & 3.4 & 0.04 & 0.03 \\
\hline $\mathrm{SE}$ & $77.9 \pm 0.2$ & 21.1 & 40.0 & 12.5 & 3.2 & 0.10 & 0.04 \\
\hline SI & $78 \pm 1.5$ & 20.4 & 40.2 & 11.3 & 3.6 & 0.10 & 0.04 \\
\hline SP & $80 \pm 0.5$ & 16.5 & 42.5 & 12.2 & 3.5 & 0.15 & 0.06 \\
\hline $\mathrm{T}$ & $80 \pm 0.4$ & 13.6 & 41.4 & 11.5 & 3.6 & 0.25 & 0.08 \\
\hline $\mathrm{U}$ & $75 \pm 1.0$ & 20.2 & 39.3 & 11.3 & 3.5 & 0.09 & 0.04 \\
\hline
\end{tabular}

a consequence of the methods of collection (light-trap and scoop-net, see 'Field sampling'). Ammonia is well documented as the major form of dissolved nitrogen excreted by the diverse animal taxa that occur as marine zooplankton (Ikeda et al. 2000). Consequently, comparing the present metabolic data on fishes with those of marine epipelagic zooplankton measured using similar sealed chamber methods is of interest. In terms of DM, the entire body mass range of the epipelagic zooplankton analyzed by Ikeda (1985) was 0.002 to $400 \mathrm{mg}$, with which the DM range of fishes in this study overlaps perfectly. Body N mass and temperature data of each fish in Table 2 were substituted for the global model for oxygen consumption rates: $\ln R=-1.7412+0.8505 \times \ln N+0.0636$ $\times t$, and ammonia excretion rates: $\ln E=-0.9657+0.836$ $\times \operatorname{lnN}+0.0656 \times t$, of epipelagic zooplankton (Ikeda
1985). $\mathrm{N}$ instead of DM is used as a unit of body mass to reduce variation originating from diverse body composition among animal taxa (Ikeda 1985). Wilcoxon signed-rank tests revealed that $\mathrm{R}$ values predicted from the model were similar to those observed ( $p>0.25)$, but E values from the model were significantly different from those observed ( $\mathrm{p}<0.001$ ) (Fig. 3). Overall, the observed E was $70 \%$ of that predicted, implying that fishes with equivalent body $\mathrm{N}$ masses to those of zooplankton consume oxygen at the same rate but excrete less ammonia than zooplankton under similar thermal regimes.

\section{Metabolic O:N ratios}

The O:N ratios (17 to 104) of the 29 fishes of this study implied the predominance of lipid/carbohydrate-oriented metabolism. Taking into account that the fishes were placed in filtered seawater (i.e. starved) for 1 to $5 \mathrm{~h}$ during experiments (see 'Metabolic measurements'), a lower contribution of protein as a metabolite is consistent with previous results (14 to $36 \%$ of the total metabolites) on rainbow trout Oncorhynchus mykiss, Nile tilapia Oreochromis niloticus, sockeye salmon $O$. nerka and others that were not fed (see review of Wood 2001). According to Wood (2001), the major metabolite in fish fed to satiation is protein but in starved fish it is lipid followed by protein or carbohydrate.

Presently available information about O:N ratios on wild marine fishes is limited to the Peruvian anchovy (Whitledge \& Packard 1971) and 4 juvenile fishes (Cypselurus sp., Galeoides sp., Longirostrum delicatissimus, Ranzania laevis) from the epipelagic zones of the tropical Indian Ocean and subtropical Pacific Ocean (Ikeda 1974). All of these O:N ratios (13 to 22), determined with sealed chamber methods that were similar to those of the present study, were at the lower range of the results from the present study (17 to 104). Apart from differences in fish species studied, the discrepancy between this study and previous studies may 

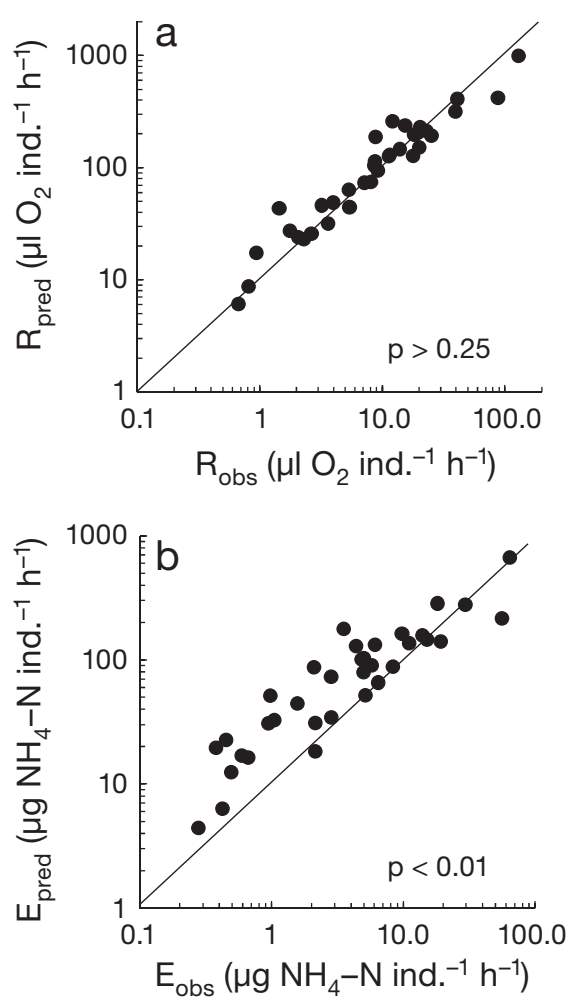

Fig. 3. Comparisons of (a) oxygen consumption rates observed $\left(\mathrm{R}_{\mathrm{obs}}\right)$ with those predicted $\left(\mathrm{R}_{\text {pred }}\right)$ and (b) ammonia excretion rates observed $\left(\mathrm{E}_{\mathrm{obs}}\right)$ with those predicted $\left(\mathrm{E}_{\text {pred }}\right)$. Predicted rates were both from marine epipelagic zooplankton metabolic models of Ikeda (1985) based on fish body mass and habitat temperature data. Data points are means of 35 data sets on the 29 fish species listed in Table 2. To facilitate comparison, a 1:1 relationship was superimposed

partly be attributed to the dissimilar diets of fishes living in tropical inshore waters (present study) and those in offshore waters (Whitledge \& Packard 1973, Ikeda 1974).

Of the 29 fishes studied, Chaetodon rainfordi (CHR), Chromis viridis (CHA) and Scatophagus sp. (SCA) are characterized by anomalously greater metabolic O:N (74 to 104) and body C:N ratios (4.3 to 4.7) compared with those of the other fishes (Fig. 4). As well as the feeding conditions discussed in the previous paragraph, food quality (specially $\mathrm{N}$ composition) has been documented to affect the O:N ratios of various marine zooplankton (Ikeda et al. 2000) and marine benthic animals (Mukai et al. 1989). While main diets of most fishes used in the present study are considered to be from relatively N-rich zoobenthos, zooplanktonic and/or nektonic species (Hiatt \& Strasburg 1960, Russell 1983), these 3 fishes have small and/or squat bodies that may not be well suited to capturing agile prey. According to Grant (1987), these 3 fishes in the waters around Australia are known to feed on algae or sea-

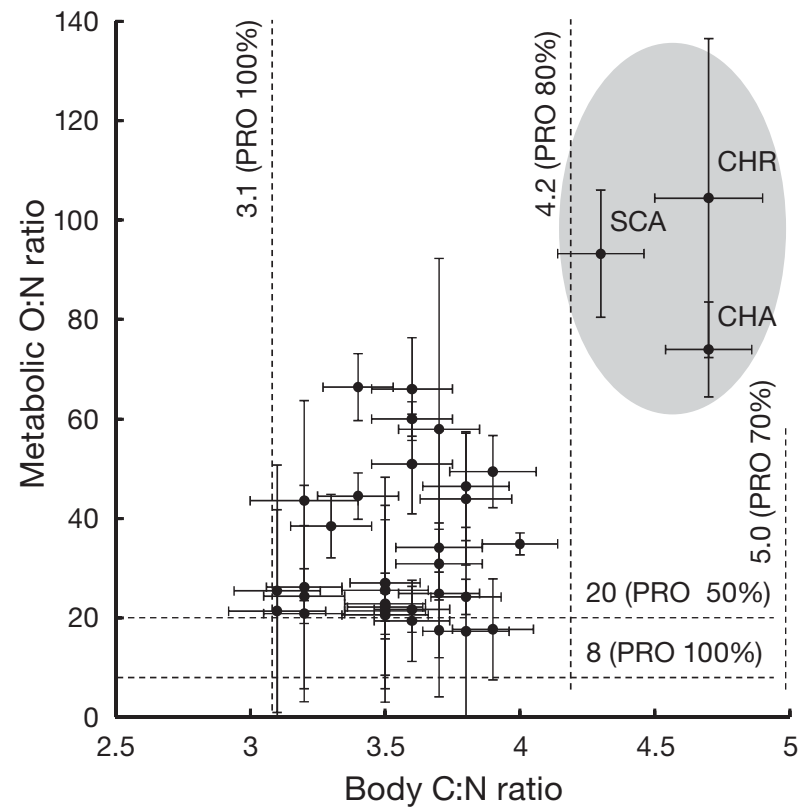

Fig. 4. Relationship between metabolic O:N ratios (by atoms) and body C:N ratios (by mass) of the 29 fish species listed in Table 2. Vertical and horizontal lines through means denote \pm 1 SD. Three isolated data sets (species code: CHR, SCA, $\mathrm{CHA}$ ) are enveloped by a light shade. Predicted metabolic O:N ratios when protein (PRO) contributed 100 and $50 \%$ of total metabolites and predicted body $\mathrm{C}: \mathrm{N}$ ratios when protein occupied 100,80 and $70 \%$ of body organic matter are superimposed by horizontal and vertical dashed lines, respectively

weeds (C. rainfordi and C. viridis) or detritus (Scatophagus sp.), all characterized by extremely low $\mathrm{N}$ composition (1 to $2 \%$ of DM, Tenore 1983, Duarte 1990). In these 3 fishes, dietary $\mathrm{N}$ may be used preferentially to build body protein by using energy derived largely from lipid/carbohydrate oriented metabolism. In addition to lower metabolic O:N ratios, lower body $\mathrm{C}: \mathrm{N}$ ratios (Fig. 4) may be a trait of life modes of these fishes caused by N-limited food nutrition. Considering the high diversity and flexibility of diets of tropical fishes (Hiatt \& Strasburg 1960, Russell 1983, Blaber 1997) combined with the abundance of detritus in the tropical inshore water environments (Qasin \& Sankaranarayaran 1972, Alongi \& Christoffersen 1992), some fishes other than these 3 species could conceivably ingest $\mathrm{N}$ poor diets opportunistically, contributing to the higher $\mathrm{O}: \mathrm{N}$ ratios of the present study as compared with those (13 to 22) of Whitledge \& Packard (1971) and Ikeda (1974). The Peruvian anchovy and 4 fishes studied by Whitledge \& Packard (1971) and Ikeda (1974), respectively, were both from offshore waters, feeding on phytoplankton (the Peruvian anchovy) or zooplankton (the 4 fishes). According to Tenore (1988), phytoplankton is more N-rich as compared with seaweeds or vascular plants. 


\section{Chemical composition and daily metabolic losses in body $\mathbf{C}$ and $\mathbf{N}$}

The chemical composition of fish changes during development (Love 1970). For example, as they grow from larvae to mature adults, the water and ash content of silvery lightfish decreases from 77 to $69 \% \mathrm{WM}$ and from 26 to $11 \% \mathrm{DM}$, respectively, while C increases from 34 to $54 \% \mathrm{DM}$ due to accumulation of lipid around the digestive tract, gonads and liver (Ikeda 1996). The chemical composition of deep-sea fish is known to differ greatly from those living in shallow waters (Childress \&Nygaard 1973). Bearing these patterns in mind, previous results from late larval or early juvenile fishes from shallow waters and with similar body mass are compared with those of the present study in Table 4. As an exception from these criteria, data from species for which body mass were unknown were included in Table 4 as 'fish/fish larvae'. Interestingly, $\mathrm{C}, \mathrm{N}$ and $\mathrm{C}: \mathrm{N}$ ratio data on grunion, sea bream, lanternfish Symbolophorus barnardi, herring, plaice and walleye pollock, all species from higher latitude seas, and 'fish/fish larvae' from a low latitude sea (off Bermuda) overlap those of the 29 fishes of the present study. However, the water contents of herring (82 to $87 \%$ ) and in 'fish/fish larvae' (84.2 to $88.1 \%$ ) were much higher than that of the 29 fishes in the present study (66.0 to $81.8 \%$ ). Higher water contents in herring and 'fish/fish larvae' could imply that their life stages are earlier than those of the 29 fishes because the water content of newly hatched larvae is high (89 to $90 \%$ ) and declines rapidly with development (Ehrlich $1974 a, b)$. This is especially true for 'fish/fish larvae' which were caught with a plankton net (Beers 1966). Ash contents of grunion (5.4 to 10.0\%, May 1971), herring ( 7.5 to $9.7 \%$, Ehrlich 1974a) and of plaice (9.3 to $10.0 \%$, Ehrlich 1974b) were less than those of the 29 fishes in the present study (11.9 to $28.6 \% \mathrm{DM}$ ). The lower ash contents of these 3 fishes may partly be due to the use of combustion temperatures $\left(500\right.$ to $\left.600^{\circ} \mathrm{C}\right)$ higher than that $\left(450^{\circ} \mathrm{C}\right)$ of this study or species-specific compositional characteristics of each species. In general, the effect of geographical position (that is, habitat temperature) was not detectable in the chemical composition data of the larval and early juvenile fishes compared in Table 4.

As a component of bones, otolithes and scales in fishes, inorganic $\mathrm{C}$ ( $a \mathrm{CaCO}_{3}-\mathrm{C}$ ) has been reported to be 0.4 to $5 \%$ of dried ash for several teleost fishes (Vinogradov 1953). If one assumes that the ash content of fishes is $18 \%$ DM (the mean of the 29 fishes of the present study), these inorganic $C$ values are equivalent to 0.1 to $0.9 \% \mathrm{DM}$, similar to the present results $(0.04$ to $0.33 \%$; Table 4). This match indicates that the respective contribution of inorganic $\mathrm{C}$ and $\mathrm{N}$ to the total $\mathrm{C}$

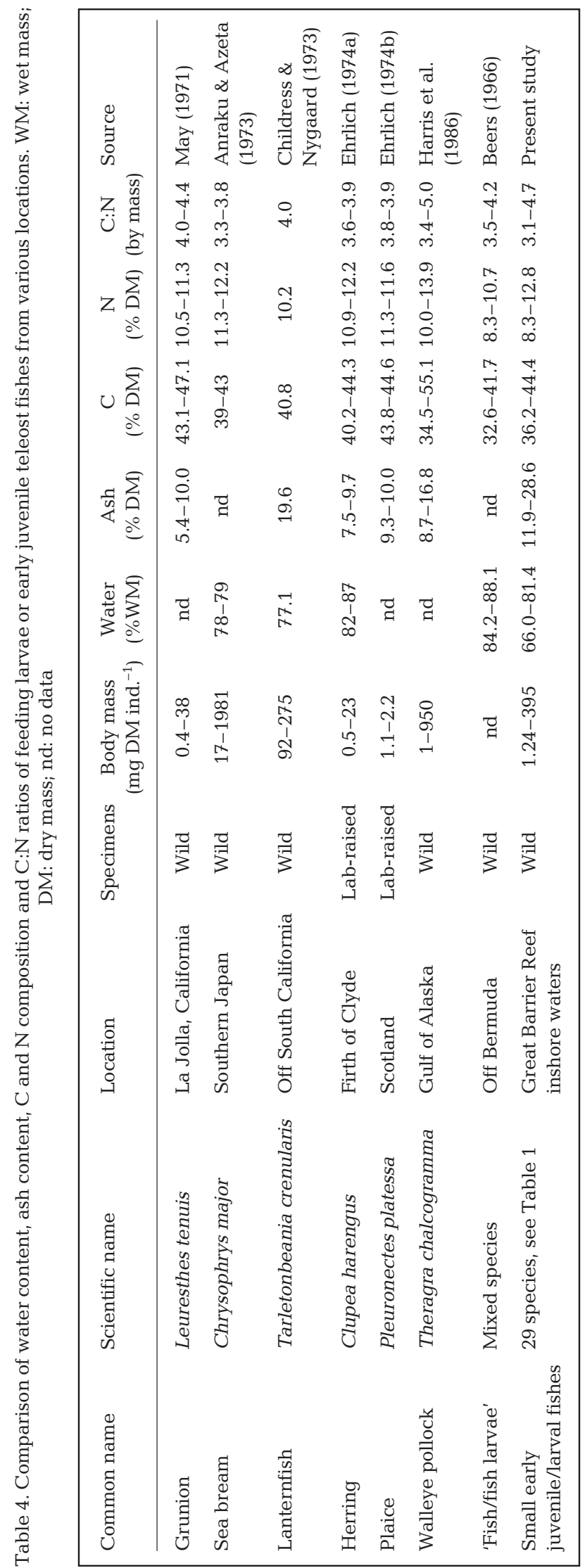


and $\mathrm{N}$ is insignificant for the 29 fish species of the present study and possibly for the other teleost fishes. With regard to inorganic $\mathrm{N}$ composition detected, $\mathrm{NH}_{4}$ may be a possible source.

On the premise that the $\mathrm{C}: \mathrm{N}$ ratio is 3.1 for organic matter composed of protein alone and 7.5 for organic matter composed of equal amount of protein and lipid (see 'Water, ash and elemental composition'), the protein composition of the 29 fish species with C:N ratios of 3.1 to 4.7 of the present study was calculated as 73 to $99 \%$. If one omits the 3 isolated data characterized by high C:N ratios (4.3 to 4.7, Fig. 4) out of the 29 fish species (e.g. resulting $\mathrm{C}: \mathrm{N}=3.1$ to 4.0 ), the percentage of protein for the organic matter was re-calculated as 83 to $99 \%$. Thus, the C:N ratio data indicate that protein is the almost exclusive component of body organic matter of the 29 fish species. The same calculation revealed that the percentage of protein is 70 to $95 \%$ for the 6 fishes plus 'fish/fish larvae' with C:N $=3.3$ to 5.0 in Table 4. The proportion of protein thus estimated will vary depending on the degree of deviation of $\mathrm{C}$ and $\mathrm{N}$ composition of protein and lipid from that given by Gnaiger \& Bitterlich (1984), but no precise information is available for tropical fish larvae material.

Daily metabolic losses in body N (DMN $=0.8$ to $9.1 \%$, with a mean of $3.3 \%$ ) were consistently less than the losses in body C (DMC $=4.3$ to $18.6 \%$ with a mean of $10.0 \%$ ) in the 29 fish species in the present study (Table 2). Fishes are known to excrete not only ammonia but also urea as the end products of protein metabolism (Wright \& Fyhn 2001, Wood 2001). Therefore, part of the reason why DMN is lower than DMC may be due to urea-N, which was not measured in this study. However, omission of urea in our calculation of DMN is not sufficient to explain the low observed DMN, since urea$\mathrm{N}$ seldom exceeds $40 \%$ of ammonia- $\mathrm{N}$ in most marine teleosts, with the exception of unusual fishes that excrete urea as the major nitrogenous excreta (Wood 2001). Lower DMN than DMC is a general feature of marine zooplankton living in various regions of the world ocean (Ikeda 1974, Ikeda \& Mitchell 1982).

There are no comparable data for DMC and DMN in other marine teleosts, with one notable exception. Whitledge (1982) determined $\mathrm{N}$ excretion (ammonia and urea) and $\mathrm{N}$ composition of the body for the nearbottom fish Diplodus senegalensis (weighing 27 to $29 \mathrm{~g}$ DM) in the upwelling region off northwest Africa and calculated DMN as 1.2 to $1.5 \%$ (0.9 to $1.1 \%$ when only $\mathrm{E}$ is considered) at $15^{\circ} \mathrm{C}$. From the E-DM relationship at 25 to $30^{\circ} \mathrm{C}$ (median: $29^{\circ} \mathrm{C}$ ) established in this study (Fig. 1), combined with a $Q_{10}=2$ for E-temperature relationships established for marine zooplankton (Ikeda 1985), DMN for D. senegalensis is computed as 1.1 to $1.2 \%$, which is close to the value (0.9 to $1.1 \%$ ) obtained by Whitledge (1982).
As a general conclusion, we demonstrated the importance of body mass to define $\mathrm{R}$ and $\mathrm{E}$ of tropical fish larvae, and resultant relationships were comparable to the $\mathrm{R}$-body mass relationships of fish and marine zooplankton by choosing appropriate body mass units (WM, DM or N). Somewhat reduced specific E of the fish larvae was evident when compared with marine zooplankton of equivalent body mass. As judged by body C:N ratios, protein is the predominant biochemical compound regulating metabolism in tropical fish larvae but this conclusion needs more detail study. A close association of $\mathrm{N}$-poor diets (detritus) with anomalously high metabolic O:N ratios and body $\mathrm{C}: \mathrm{N}$ ratios found in some fish larvae warrants further investigation for better prediction of $\mathrm{E}$ and $\mathrm{N}$ composition from the body mass data only. By knowing body mass composition data of fish populations in a tropical system, their roles in carbon and nitrogen mineralization in the system can be estimated from the R- and E-body mass relationships established in this study (Fig. 1).

Acknowledgements. We thank M. Cappo and J.M. Leis for help in fish identification, and J.H. Carleton for the use of light traps for collecting fish. We thank 3 anonymous referees for their comments, which significantly improved the manuscript. T.I. was supported by the AIMS Visiting Scientist Program.

\section{LITERATURE CITED}

Alongi DM, Christoffersen P (1992) Benthic infauna and organism-sediment relations in a shallow, tropical coastal area: influence of outwelled mangrove detritus and physical disturbance. Mar Ecol Prog Ser 81:229-245

Anraku M, Azeta M (1973) Difference of body components between artificially reared and natural sea bream: larva and young. Bull Seikai Reg Fish Res Lab 43:117-131

Beers JR (1966) Studies on the chemical composition of the major zooplankton groups in the Sargasso Sea off Bermuda. Limnol Oceanogr 11:520-528

Blaber SJM (1997) Fish and fisheries of tropical estuaries. Fish and fisheries, Ser 22. Chapman \& Hall, London

Bochdansky AB, Leggett WC (2001) Winberg revisited: convergence of routine metabolism in larval and juvenile fish. Can J Fish Aquat Sci 58:220-230

> Bray RN, Purcell LJ, Miller AC (1986) Ammonium excretion in a temperate-reef community by a planktivorous fish, Chromis punctipinnis (Pomacentridae), and potential uptake by young giant kelp, Macrocystis pyrifera (Laminariales). Mar Biol 90:327-334

Childress JJ, Nygaard MH (1973) The chemical composition of midwater fishes as a function of depth of occurrence off southern California. Deep-Sea Res 20:1093-1109

Clarke A, Johnston NM (1999) Scaling of metabolic rate with body mass and temperature in teleost fish. J Anim Ecol 68: 893-905

> Cockcroft AC, Du Preez HH (1989) Nitrogen and energy loss via nonfaecal and faecal excretion in the marine teleost Lithognathus lithognathus. Mar Biol 101:419-425

Conover RJ (1978) Transformation of organic matter. In: Kinne O (ed) Marine ecology: a comprehensive, integrated treatise on life in oceans and coastal waters, Vol IV. Dynamics. Wiley, Chichester, p 221-499 
del Giorgio PA, Duarte CM (2002) Respiration in the open ocean. Nature 420: 379-384

Duarte CM (1990) Seagrass nutrient content. Mar Ecol Prog Ser 67:201-207

Ehrlich KF (1974a) Chemical changes during growth and starvation of herring larvae. In: Blaxter JHS (ed) The early life history of fish, Vol 1. Springer-Verlag, Berlin p 301-323

Ehrlich KF (1974b) Chemical changes during growth and starvation of larval Pleuronectes platessa. Mar Biol 24: 39-48

Finn RN, Rønnestad I (2003) The effect of acute changes in temperature and light on the aerobic metabolism of embryos and yolk-sac larvae of turbot (Scophthalmus maximus). Can J Fish Aquat Sci 60:1324-1331

- Finn RN, Rønnestad I, van der Meeren T, Fyhn HJ (2002) Fuel and metabolic scaling during the early life stages of Atlantic cod Gadus morhua. Mar Ecol Prog Ser 243:217-234

Fry FEJ (1971) The effect of environmental factors on the physiology of fish. In: Hoar WS, Randall DJ (eds) Fish physiology, Vol 6. Environmental relations and behavior. Academic Press, New York, NY, p 1-99

Gnaiger E (1983) Calculation of energetic and biochemical equivalents of respiratory oxygen consumption. In: Gnaiger E, Forstner H (eds) Polarographic oxygen sensors: aquatic and physiological applications. Springer-Verlag, Berlin, p 337-345

Gnaiger E, Bitterlich G (1984) Proximate biochemical composition and caloric content calculated from elemental CHN analysis: a stoichiometric concept. Oecologia 62:289-298

Grant EM (1987) Fishes of Australia 2nd edn. EM Grant, Redcliffe

Harris RK, Nishiyama T, Paul AJ (1986) Carbon, nitrogen and caloric content of eggs, larvae, and juveniles of the walleye pollock, Theragra chalcogramma. J Fish Biol 29:87-98

Hiatt RW, Strasburg DW (1960) Biological relationships of the fish fauna on coral reefs of the Marshall Islands. Ecol Monogr 30:65-127

Ikeda T (1974) Nutritional ecology of marine zooplankton. Mem Fac Fish Hokkaido Univ 22:1-97

> Ikeda T (1985) Metabolic rates of epipelagic marine zooplankton as a function of body mass and temperature. Mar Biol 85:1-11

Ikeda T (1996) Metabolism, body composition, and energy budget of the mesopelagic fish Maurolicus muelleri in the Sea of Japan. Fish Bull 94:49-58

> Ikeda T, Mitchell AW (1982) Oxygen uptake, ammonia excretion and phosphate excretion by krill and other Antarctic zooplankton in relation to their body size and chemical composition. Mar Biol 71:283-298

Ikeda T, Torres JJ, Hernández-León S, Geiger SP (2000) Metabolism. In: Harris RP, Wiebe PH, Lenz J, Skjoldal HR, Huntley M (eds) ICES zooplankton methodology manual. Academic Press, London, p 455-532

Kutty MN (1978) Ammonia quotient in sockeye salmon (Oncorhynchus nerka). J Fish Res Board Can 35:1003-1005

Leis JM, Rennis DS (1983) The larvae of Indo-Pacific coral reef fishes. University of Hawaii Press, Honolulu, HI

Love RM (1970) The chemical biology of fishes. Academic Press, London

May RC (1971) Effects of delayed initial feeding on larvae of the grunion, Leuresthes tenuis (Ayres). Fish Bull 69:411-425

Mayzaud P, Conover RJ (1988) O:N atomic ratio as a tool to describe zooplankton metabolism. Mar Ecol Prog Ser 45: 289-302

Editorial responsibility: Marsh Youngbluth,

Fort Pierce, Florida, USA
McCarthy JJ, Whitledge TE (1972) Nitrogen excretion by anchovy (Engraulis mordax and E. ringens) and jack mackerel (Trachurus symmetricus). Fish Bull 70:395-401

> Meekan M, Wilson S, Halford A, Retzel A (2001) A comparison of catches of fishes and invertebrates by two light trap designs, in tropical NW Australia. Mar Biol 139: $373-381$

Meyer JL, Schultz ET (1985) Migrating haemulid fishes as a source of nutrients and organic matter on coral reefs. Limnol Oceanogr 30:146-156

> Meyer JL, Schultz ET, Helfman GS (1983) Fish schools: an asset to corals. Science 220:1047-1049

Mukai H, Koike I, Nishihira M, Nojima S (1989) Oxygen consumption and ammonia excretion of mega-sized benthic invertebrates in a tropical seagrass bed. J Exp Mar Biol Ecol 134:101-115

Nilsson GE, Östlund-Nilsson S (2006) Hypoxia tolerance in coral reef fishes. In: Val AL, Almeida-Val VMF, Randall DJ (eds), The physiology of tropical fishes, Fish physiology Vol. 21, Elsevie, p 583-596

Post JR, Lee JA (1996) Metabolic ontogeny of teleost fishes. Can J Fish Aquat Sci 53:910-923

- Qasin SZ, Sankaranarayaran VN (1972) Organic detritus of a tropical estuary. Mar Biol 15:193-199

> Russell BC (1983) The food and feeding habits of rocky reef fish of north-eastern New Zealand. NZ J Mar Freshw Res 17:121-145

Strickland JDH, Parsons TR (1972) A practical handbook of seawater analysis, 2nd edn. Bull Fish Res Board Can 167

> Tenore KR (1983) What controls the availability to animal of detritus derived from vascular plants: organic nitrogen enrichment or caloric availability? Mar Ecol Prog Ser 10: 307-309

Tenore KR (1988) Nitrogen in benthic food chains. In: Blackburn TH, Sørensen J (eds) Nitrogen cycling in coastal marine environment. John Wiley, Chichester, p 191-206

Terjesen BF (2008) Nitogen excretion. In: Finn RN, Kapoor BG (eds) Fish larvae physiology. Scientific Publishers, Enfield, NH, p 263-302

Vinogradov AP (1953) The elementary chemical composition of marine organisms. Sears Foundation for Marine Research, New Haven, CT

Whitledge TE (1978) Regeneration of nitrogen by zooplankton and fish in the northwest Africa and Peru upwelling ecosystems. In: Boje $\mathrm{R}$, Tomeczak (eds) Upwelling ecosystems. Springer-Verlag, Berlin, p 90-100

Whitledge TE (1982) Regeneration of nitrogen by the nekton and its significance in the northwest Africa upwelling ecosystem. Fish Bull 80:327-335

Whitledge TE, Packard TT (1971) Nutrient excretion by anchovies and zooplankton in Pacific upwelling regions. Invest Pesq 35:243-250

Winberg GG (1956) Rate of metabolism and food requirements of fishes. Belorussian State University, Minsk, J Fish Res Board Can Transl Ser No. 194

Wood CM (2001) Influence of feeding, exercise, and temperature on nitrogen metabolism and excretion. In: Wright PA, Anderson PM (eds) Nitrogen excretion, Fish physiology, Vol. 20. Academic Press, San Diego, CA, p 1201-237

Wright PA, Fyhn HJ (2001) Ontogeny of nitrogen metabolism and excretion. In: Wright PA, Anderson PM (eds) Nitrogen excretion, Fish physiology, Vol. 20. Academic Press, San Diego, CA, p 149-200

Submitted: October 12, 2010; Accepted: May 26, 2011

Proofs received from author(s): July 28, 2011 